\title{
Upregulation of c-Met by Hepatocyte Growth Factor in Retinal Pigment Epithelial Cells
}

\author{
Jonathan Blaize ${ }^{1}$, William L’Amoreaux ${ }^{1,2}$ \\ ${ }^{1}$ The College of Staten Island, The City University of New York, 2800 Victory Blvd. Staten Island, \\ New York 10314 \\ ${ }^{2}$ Advanced Imaging Facility of the College of Staten Island, 2800 Victory Blvd., Staten Island, NY \\ 10314
}

Outer segment (OS) binding, ingestion, and digestion are crucial tasks performed by the retinal pigment epithelium (RPE); in turn RPE are characterized in part by their ability to effectively phagocytize spent OS generated as byproducts of photoreceptor renewal. Impairment of RPE in any capacity can severely disrupt visual function, culminating with eventual and irreversible blindness.

Hepatocyte growth factor (HGF) is a glycoprotein responsible for mediating epithelial mesychymal interactions and is secreted by the RPE [1] and influences RPE migration [2]. A putative receptor has been identified in RPE that is phosphorylated in the presence of HGF [3]. The cognate receptor for HGF is the proto-oncogene receptor tyrosine kinase cMET [4]. Activation of cMET on epithelial cells leads to cell dissociation, cell division or differentiation and morphogenesis [5]. Activation of c-Met in corneal epithelium leads to subsequent activation of the JAK/STAT pathway [6]. The JAK/STAT pathway is also implicated in readying cells for phagocytosis [7]. Finally, HGF can upregulate expression of integrins in MDCK cells [8]. These circumstantial evidence suggests that HGF may play a role in preparing the RPE for phagocytosis of OS. Our laboratory's long-term goal is to address the role(s) of HGF in preparing the RPE for phagocytosis.

Human RPE cells (ARPE19; ATCC) were cultured in DMEM/F12 medium containing 3\% fetal calf serum, $2.5 \mathrm{mM} \mathrm{L-glutamine}$ and $18 \mathrm{mM}$ sodium bicarbonate at $37^{\circ} \mathrm{C}$ and $5 \% \mathrm{CO}_{2}$. When cultures were $\sim 50 \%$ confluent, they were adapted for $24 \mathrm{hr}$ to serum-free medium containing ITS. Cells were treated with HGF in concentrations from $0-25 \mathrm{ng} / \mathrm{ml}$.

[1] P. M. He, et al., Biochem Biophys Res Commun, 249 (1998) p. 253.

[2] Y. Miura, et al., Jpn J Ophthalmol, 47 (2003) p. 268.

[3] K. Lashkari, N. Rahimi, and A. Kazlauskas, Invest Ophthalmol Vis Sci, 40 (1999) p. 149.

[4] L. Naldini, et al., Oncogene, 6 (1991) p. 501.

[5] E. Gherardi, et al., Symp Soc Exp Biol, 47 (1993) p. 163.

[6] Q. Liang, et al., Invest Ophthalmol Vis Sci, 39 (1998) p. 1329.

[7] S. V. Shirshev and E. G. Orlova, Biochemistry (Mosc), 70 (2005) p. 841.

[8] S. J. Chiu, et al., J Biomed Sci, 9 (2002) p. 261. 


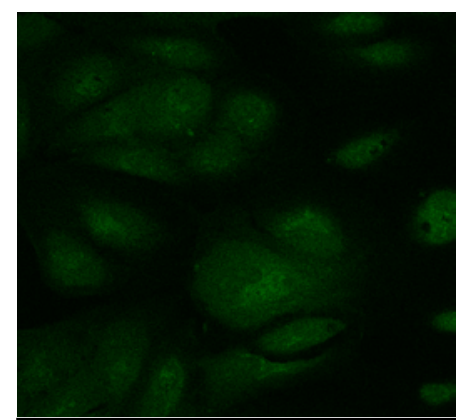

$>$ Figure 1A : control cells express low levels of cMET.

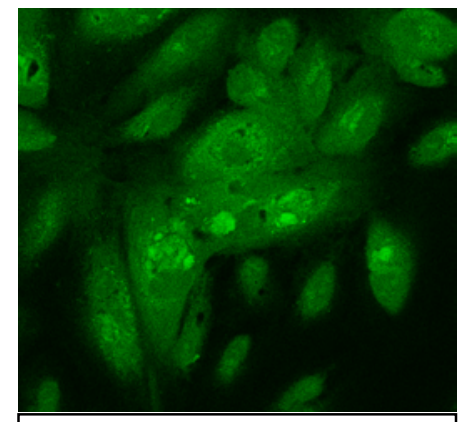

$>$ Figure 1D : cells treated with $15 \mathrm{ng} / \mathrm{ml}$ HGF show a significant increase in cMET expression.

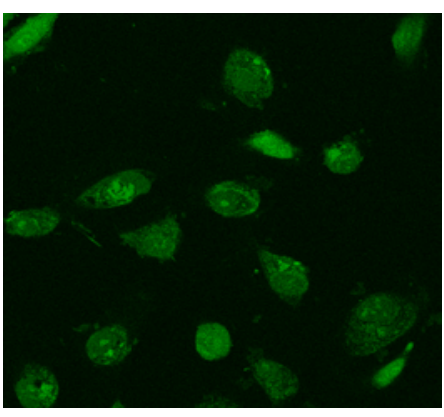

$>$ Figure $1 \mathrm{G}$ : cells treated with $25 \mathrm{ng} / \mathrm{ml}$ HGF show a significant decrease in cMET expression over $20 \mathrm{ng} / \mathrm{ml}$, however expression remains far greater than controls.

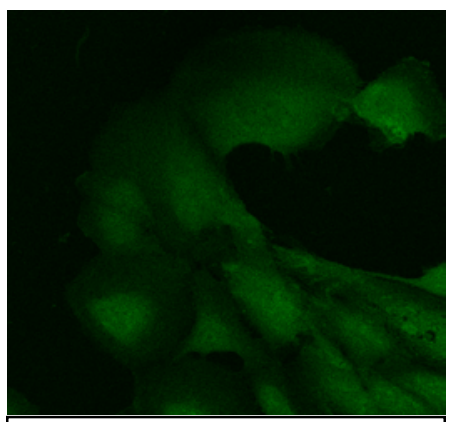

$>$ Figure 1B : cells treated with 5 $\mathrm{ng} / \mathrm{ml}$ HGF show a nonsignificant increase in cMET

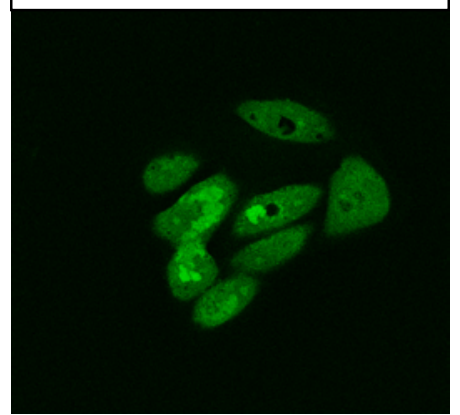

$>$ Figure 1E : cells treated with $17 \mathrm{ng} / \mathrm{ml} \mathrm{HGF}$ show a significant increase in cMET expression over controls, but this was not significant from $15 \mathrm{ng} / \mathrm{ml}$

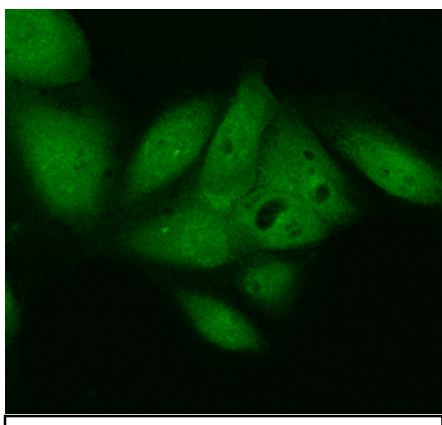

$>$ Figure 1C : cells treated with 10 $\mathrm{ng} / \mathrm{ml}$ HGF show a non-

significant increase in cMET

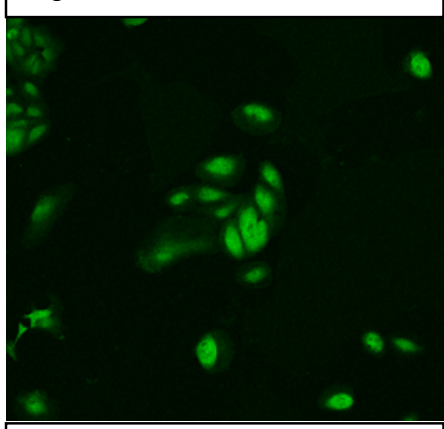

$>$ Figure $1 \mathrm{~F}$ : cells treated with 20 or $25 \mathrm{ng} / \mathrm{ml}$ HGF show an increase expression of cMET over controls, yet these concentrations may also repress some expression. 